Efficient Vol 2 (1) (2019): 331-340 DOI: https://doi.org/10.15294/efficient.v2i1.28399

\title{
EFFICIENT
}

Indonesian Journal of Development Economics https://journal.unnes.ac.id/sju/index.php/efficient

\section{the Effect of One-Way Street Policy Towards the Income of MSME Sector}

\author{
Lely Kusumaning Ayu ${ }^{1 \varpi}$, Etty Soesilowati ${ }^{2}$ \\ Jurusan Ekonomi Pembangunan, Fakultas Ekonomi, Universitas Negeri Semarang \\ Permalink/DOI: https://doi.org/10.15294/efficient.v2i1.28399 \\ Received: July 2018 ; Accepted: October 2018 ; Published: January 2019
}

\begin{abstract}
The aims of this study was to analyze the effect of implementation of one-way street policy towards the income and to find out how the MSME (Micro, Small and Medium Enterprise) strategy in MH Thamrin-Gajah Mada street. The method that was used in this research was percentage description, with data analysis tools Paired Samples T-Test and SWOT analysis. Data is collected through observation, interviews and documentation. The results of this study showed that (1) the value of paired test for the average income of business actor in goods sector has decreased by 34\%, then for service businesses has decreased by $40 \%$. (2) The results of SWOT analysis explained that the direction strategy of MSME sector development was in growth and development phase with IFE (Internal Factor Evaluation) scores = 2.86 and EFE (External Factor Evaluation) = 3.07, so the development strategy of MSME sector is development business in another place, business coaching by related agencies, business innovation, creating promotions by using social media, training, maintaining product selling prices, and coordination between agencies related to the business actor.
\end{abstract}

Keywords: Goverment Policy, Sector UMKM, Analyze

\begin{abstract}
Abstrak
Tujuan dari penelitian ini adalah untuk menganalisis pengaruh penerapan kebijakan satu arah jalan terhadap pendapatan dan untuk mengetahui bagaimana strategi UMKM (Usaha Mikro, Kecil dan Menengah) di jalan MH Thamrin-Gajah Mada. Metode yang digunakan dalam penelitian ini adalah deskripsi persentase, dengan alat analisis data Paired Samples T-Test dan analisis SWOT. Data dikumpulkan melalui observasi, wawancara dan dokumentasi. Hasil penelitian ini menunjukkan bahwa (1) nilai paired $t$ test untuk pendapatan rata-rata pelaku usaha di sektor barang mengalami penurunan sebesar 34\%, maka untuk bisnis jasa mengalami penurunan sebesar 40\%. (2) Hasil analisis SWOT menjelaskan bahwa arah strategi pengembangan sektor UMKM adalah pada fase pertumbuhan dan perkembangan dengan skor IFE (Evaluasi Faktor Internal) = 2,86 dan EFE (Evaluasi Faktor Eksternal) $=3,07$, sehingga strategi pengembangan sektor UMKM adalah pengembangan bisnis di tempat lain, pembinaan bisnis oleh agen terkait, inovasi bisnis, membuat promosi dengan menggunakan media sosial, pelatihan, menjaga harga jual produk, dan koordinasi antara agen terkait dengan pelaku bisnis.
\end{abstract}

Kata Kunci: Kebijakan Pemerintah, Sektor UMKM, Analisis

How to Cite: Ayu, L., \& Soesilowati, E. (2019). the Effect of One-Way Street Policy Towards the Income of MSME Sector. EFFICIENT Indonesian Journal of Development Economics, 2(1), 331-340. https://doi.org/10.15294/efficient.v2i1.28399

(C) 2019 Semarang State University. All rights reserved

\begin{tabular}{lc}
\hline Alamat Korespondensi : & ISSN 2655-6197 \\
Alamat: Gedung L2 Lantai 2 FE Unnes & \\
Kampus Sekaran, Gunungpati, Semarang, 50229 & \\
E-mail : Lelykusuma99y@gmail.com &
\end{tabular}




\section{INTRODUCTION}

Traffic congestion conditions which was caused by the high levels of vehicle use and parking along the road, then inappropriate traffic lights which cause congestion at various points in Semarang city that makes the government of Semarang city issue engineering One-Way Street Policy to reduce congestion in Semarang city.

Table 1. The Number of Private Vehicles in Semarang City Period 2012-2016

\begin{tabular}{lllll}
\hline No & Year & $\begin{array}{l}\text { Two } \\
\text { Wheels }\end{array}$ & $\begin{array}{l}\text { Four } \\
\text { Wheels }\end{array}$ & Total \\
\hline 1 & 2012 & 66.921 & 17.893 & 84.814 \\
2 & 2013 & 67.279 & 18.230 & 85.509 \\
3 & 2014 & 77.373 & 20.517 & 97.890 \\
4 & 2015 & 65.436 & 22.392 & 87.828 \\
5 & 2016 & & 24.080 & 24.080 \\
\hline
\end{tabular}

Source: Directorate of Traffic, Central Java Regional police

Based on those data it can be known that the number of private vehicle users has experienced an increasing trend. This is the first factor which make the government issued policy, namely: 1. Therewas a response from the government of Semarang City that carried out Public Service regulation. 2. Congestion level that occurs in those area. From those two factors, then the government ofSemarang city issued one-way policy which applies in JMhThamrin - Gajah Mada Street, Semarang City. The existence of new policy made by the government of Semarang city regarding the Business Environment is related to the changing of one-way lane in MH Thamrin-Gajah Mada Street, Semarang City, where the location of those two roads is in Regional Regulation of Semarang city Number 2 Year 2002 about The Detail Plan of City Layout (RDTRK) The Municipality of Level Region II Semarang City Region Section I (BWK 1) which covers the District of Central
Semarang, that in the area of MH ThamrinGajah Mada Street, Semarang City is residential area, offices and trade-services.

The implementation of this policy has made business actors have done spontaneous reaction because there are changes (Sales Revenue) that obtained by traditional sector MSME actors. The new policy, made by the government of Semarang city is considered very detrimental to MSME traditional sectors which are on the route.

The implementation of one-way street on both roads have an effect on economic activity and the price land in the surrounding area. One of the effects thatemerged after the policy has been operated is MSMEsector at MH Thamrin - Gajah Mada Streetwhich was initially has many consumers that mostly students, employees and other communities, then in the end many MSME has experienced polemic such as many MSME food outlets experienced a decline in the number of consumers or in other words, the number of consumers has decreased dramatically so that the decline in consumer demand cannot be avoided. By the existence of drastic decline in the consumers demand, it clearly affects the income of outlets of those MSME sector.

Because of the existence of problems which arose by one-way street policy, here the researcher wants to know more about how much the changes in MSME sector income before and after the implementation of one-way street in $\mathrm{MH}$ Thamrin-Gajah Mada Street, Semarang City, then if there is transformation in business environment as happened on both roads, then business actors can carry out new strategies in doing business development in the future.

The aims of this study are to analyze the effect of implementation of one-way street policy on the income and to find out how the MSME strategy in JMH Thamrin - Gajah Mada Street. 


\section{RESEARCH METHODS}

This study used percentage description analysis method by using quantitative research approach. The variables in this study are the income before and after the implementation of one-way street policy. For the research on the income development strategy, business development at $\mathrm{MH}$ Thamrin-Gajah MadaStreet with the limitation of research object on variables that have been categorized in internal factors and external factors.

Internal variables in this study include Capital, Marketing and Entrepreneurial Mindset. SWOT variables external factors include Competition, Economic Conditions, Government Policy, and Technology.

The population in this study was all MSME outlets along MH ThamrinGajah Mada Street with non-foreign private ownership status. The sample of this study were 83 MSME outlets along the road area by using purposive sampling method, and that the sample of this study is MSME sector that is engaged in services and goods which has been previously planned by the researcher to become the object of this research.

Sources of data in this study are respondents that is people who respond or answer the researcher's questions, both written and oral questions because this study uses interview and questionnaire in collecting the data. The respondents are the owner or person in charge of 83 selected MSME outlets.

In collecting the data, the writer used a method or technical interview, field observationwith questionnaire. To analyze the effect of implementation of one-way street policy towards the income of MSME outlets in MH Thamrin - Gajah Mada Street, then the researcher used Paired - Samples $\mathrm{T}$ Test, with the following formulation:

$$
t=\frac{\overline{X_{1}}-\overline{X_{2}}}{\sqrt{\frac{s_{1}{ }^{2}}{n_{1}}+\frac{s_{2}{ }^{2}}{n_{2}}-2 r\left(\frac{s_{1}}{\sqrt{n_{1}}}\right)\left(\frac{s_{2}}{\sqrt{n_{2}}}\right)}}
$$

Description:

$\left(x \_1\right)^{-}=$Average income of merchant before one-way policy

$\left(\mathrm{x} \_2\right)^{-}=$Average income of merchant after one-way policy

$\mathrm{s} \_1_{-1}=$ Standard deviation of merchant income before one-way policy

s_2 = Standard deviation of merchant income after one-way policy

$\mathrm{n} \_(1)=\mathrm{n}_{-}(1)=$ Total merchant income before one-way policy

$\mathrm{n} \_2=\mathrm{n} \_2=$ Total merchant income after one-way policy

The calculation of paired sample t test used SPSS software version 16.0 with decision making as follows; if the probability is $>0.05$, then $\mathrm{H}_{\mathrm{o}}$ is accepted and $\mathrm{H}_{\mathrm{a}}$ is rejected, so there is no difference in the merchant income before and after the implementation of policy. And If the probability is <0.05, then $\mathrm{H}_{\mathrm{o}}$ is rejected and $\mathrm{H}_{\mathrm{a}}$ is accepted so there is difference inthe merchant income before and after the implementation of policy. The use of SWOT analysis was done to analyze the internal and external factors of the businessman in business environment along MH Thamrin-Gajah Mada Street, so that it can be known what factors which become the strength, the weakness, and opportunity and threats in those business environment. This analysis base on the strategy to optimize strengths and opportunities (Fafurida, et al, 2016).

\section{RESULTS AND DISCUSSION}

The discussion was carried out by knowing the characteristics of the types of MSME at MH Thamrin-Gajah Mada Street in Semarang City, analyzing the effect of one- 
way street policy on merchant income with Paire-Samples $\mathrm{T}$ test, then identifying the internal and external environmental conditions, continued with SWOT analysis and general electric analysis (GE) to determine the development strategy of MSME in MH Thamrin-Gajah Mada Semarang City. The table 2 shows that from 83 respondents, the majority of respondents have UMKM or business types of goods as many as 63 people or $75.90 \%$ and 20 respondents or as much as $24.09 \%$ have service sector business. From the business sector, either goods or services business can be explained, as many as 63 goods business sector consist of 50 culinary business, 11 fashion business, 1 building business, 1 ink center store. The service sector consists of motorbike repair, motorbike and car counters that is 20 existing businesses. From these results obtained respondents analysis which is the dominance of UMKM sector is goods. The table 2 shows that from 83 respondents, the majority of respondents have UMKM or business types of goods as many as 63 people or $75.90 \%$ and 20 respondents or as much as $24.09 \%$ have service sector business. From the business sector, either goods or services business can be explained, as many as 63 goods business sector consist of 50 culinary business, 11 fashion business, 1 building business, 1 ink center store. The service sector consists of motorbike repair, motorbike and car counters that is 20 existing businesses. From these results obtained respondents analysis which is the dominance of UMKM sector is goods. To analyze the effect of implementation of one-way street policy towards the income of MSME outlets in MH Thamrin-Gajah Mada Street, then the researcher used Paired-Samples $T$ Test. Paired-Samples $\mathrm{T}$ Test is a different test of two paired samples. Paired samples are the same object but experience different treatments.

Table 2 The Characteristics of the Types of UMKM along MH Thamrin - Gajah MadaStreet, Region of Semarang City

\begin{tabular}{ll}
\hline Business Sector & Total \\
\hline Goods & \\
Culinary & 50 \\
Fashion & 11 \\
Other goods business & 2 \\
Total & 63 \\
Services Workshops, decoration & \\
services, car and motorcycle seat & 20 \\
installation services & \\
Total & 20 \\
Total number & 83 \\
\hline
\end{tabular}

Source:Primary Data, Data processed 2018

The study was conducted on the income of MSME on MH Thamrin-Gajah Mada road before and after the implementation of the one-way road policy. Following are the Paired $\mathrm{T}$ test results using the help of SPSS version 16.0 application:

Table 3. (Paired-Samples T Test) of Goods Business

\begin{tabular}{ccccc}
\hline & \multicolumn{3}{c}{ Paired Samples Test } \\
\hline & $\mathrm{T}$ & $\mathrm{df}$ & Sig. (2-tailed) \\
Pair 1 before & - & & & \\
after & 5.314 & 62 & .000
\end{tabular}

Source:Primary Data, Data processed 2018

Table 4 (Paired-Samples T Test) off Services Business

\begin{tabular}{cccc}
\hline & \multicolumn{3}{c}{ Paired Samples Test } \\
\hline & $\mathrm{T}$ & $\mathrm{df}$ & Sig. (2-tailed) \\
$\begin{array}{c}\text { Pair 1 before } \\
\text { after }\end{array}$ & 5.685 & 19 & .000 \\
\hline Source: & Primary & Data, Data & processed 2018
\end{tabular}


The value of $t$ research on goods business (5.314) > t table (1.99962) then Ho is rejected and $\mathrm{Ha}$ is accepted, and for the service business the value of $t$ research (5.685) $>\mathrm{t}$ table (2.10092). So it can be said that there is a difference in the income of MSME outlets in MH ThamrinStreet before and after the implementation of one-way street in MSME Goods and Services sectors.

The results for MSME Goods sector indicate that the merchant income before the implementation of policy is Rp. 15,950,000.00 per month, whereas after the implementation of policyis Rp. 10.4922.100,oo per month, then from the calculation results the average income of Goods sector decreased by $34 \%$.

Table 5. The Average Income of Goods Business Before-After Policy

\begin{tabular}{cccccc}
\hline \multicolumn{5}{c}{ Paired Samples Statistics } \\
\hline & & Mean & N & Deviation & Mean \\
Pair & Before & 15.95 & 63 & 15.899 & 2.003 \\
1 & After & 10.4921 & 63 & 10.95279 & 1.37992 \\
\hline \multicolumn{3}{l}{ Source : Primary Data, Data processed 2018 }
\end{tabular}

Table 6. The Average Income of Service Business Before-After Policy

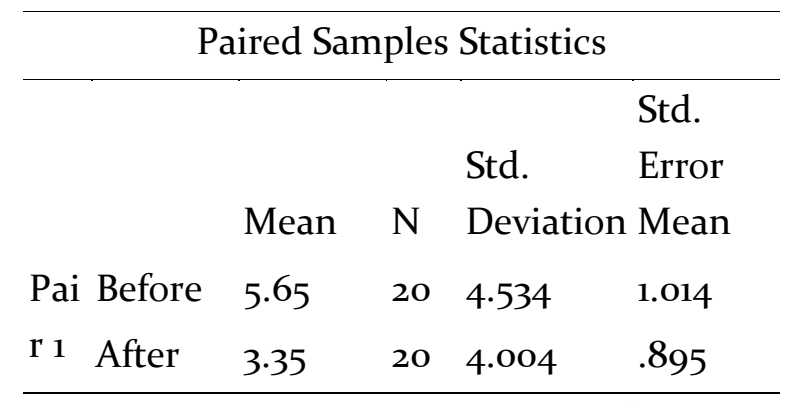

Source:Primary Data, Data processed 2018

The income of Service business sector before the implementation of policy is Rp. 5,650,000.oo per month, after the implementation of policy is Rp. 3,350,000.00 per month, from the calculation results, the average income of service business sector decreases by $40 \%$.
Furthermore, the discussion was carried out by identifying the condition of the internal environment and the external environment, followed by SWOT analysis and analysis of general electrics (GE) to determine the development strategy of MSMEs at Jalan Mh Thamrin - Gajah Mada Semarang City. Internal environment Includes: (1) Capital (2) Marketing (3) Entrepreneurial Mindset.

The capital in this study includes working capital requirements, business capital structure, solvency (long-term debt fulfillment obligations) and liquidity (shortterm debt fulfillment obligations) that can be done by the MSME sector. (1) The average of working capital used by the actors of MSME in $\mathrm{MH}$ Thamrin-Gajah Mada Street is $<\mathrm{Rp}$. 5,000,00o. (2) Capital structure is diverse but most of the capital used in goods and services businesses is more than $70 \%$ which is their own capital. (3) The respondents did not have difficulty in paying debt.

Marketing in this study includes the quality of goods or services produced, pricing, and marketing are and promotional activities which have been done by MSME sector. (1) Promotional activities, most of MSME actors never promote their products. (2) Pricing, generally the MSME actors setting the prices relatively same as its competitors. (3) Marketing area, most MSME is only in one location. (4) Most of business actors do not mention their qualified product.

Entrepreneurial Mindset in this study includes innovation in business processes, other income outside their business, the obstacles in running the business. (1) Most of MSME actors in MH Thamrin-Gajah MadaStreet do not have other income outside their business. (2) Most of MSME actors do not have business innovation in developing their business. (3) The obstacles which become the main problem at this time is the 
existence of government policy by implementing one - way street which causes low level of accessibility.External EnvironmentIncludes: (1) competition, (2) economic conditions, (3) government policy, (4) technology. Competition in this study includes the social conditions that exist between entrepreneurs, the number of competitors, buyer strength, and the superiority of products or services offered. (1) The business environment in $\mathrm{MH}$ Tahmrin-Gajah Mada Street has good social conditions between entrepreneurs. (2) Competition along $\mathrm{MH}$ Thamrin-Gajah Mada Street is common. (3) Averagely the superiority of the products offered is the same.

Table 7. SWOT Analysis of MSME in MH Thamrin-Gajah Mada Street, Semarang City

\begin{tabular}{|c|c|}
\hline Strength & Weakness \\
\hline $\begin{array}{l}\text { 1. Ease of accessing capital loan sources, } \\
\text { 2. A balanced capital structure between own } \\
\text { capital and debt, } \\
\text { 3. Medium and high average HR, } \\
\text { 4. The business location is very strategic, } \\
\text { 5. The selling price of business product is } \\
\text { relatively the same as the competitor, } \\
\text { 6. There are various types of MSME which are } \\
\text { available with their respective advantages. }\end{array}$ & $\begin{array}{l}\text { 1. No promotional activities, } \\
\text { 2. Small working capital, } \\
\text { 3. Government policies that are less } \\
\text { conducive, especially the } \\
\text { implementation of one-way street, } \\
\text { 4. The low use of technology, } \\
\text { 5. Lack of external contributions, } \\
\text { especially the government itself, } \\
\text { associations, and others in supporting } \\
\text { the development of MSME. }\end{array}$ \\
\hline
\end{tabular}

Opportunities

1. The use of technology that can support the business,

2. Good social conditions entrepreneurs,

3. Innovation in running the business,

4. Coaching for MSME owners,

5. Can open similar businesses elsewhere to increase income,

6. Can do better promotional strategy to attract many consumers.

\section{Threats}

1. Government policies that are not optimal,

2. There is no help from the government in business development,

3. There is conflict between employers and the government,

4. Low level of accessibility,

5. There is no formal promotion, so maybe there is no upcoming development of new buyers.

Source: Primary Data, Data processed 2018

Economic conditions in this study include the business environment that exists along the road before and after the implementation of policy, the level of buyer interest by the community, the level of regional minimum wages. (1) The MSME in MH Thamrin-Gajah Mada Street has very stable and conducive business environment (2) $90 \%$ of all the total respondents experienced changes in the income and decline in the number of customers after the implementation of one-way street policy. (3) the level of Regional Minimum wages (RMW) is one of the factors 
which can affect the income. Government Policy. In this study included Government policy of Semarang City towards the implementation of one-way street which existed at several points of the road and the effect that had been caused by the policy.

Table 8. Skor Internal Facktor Evaluation

\begin{tabular}{|c|c|c|}
\hline No & Strategic Factors of Internal Strength & Score \\
\hline 1 & Ease of accessing capital loan sources & 0,400 \\
\hline 2 & A balanced capital structure between own capital and debt & 0.315 \\
\hline 3 & Medium and high average HR & 0,360 \\
\hline 4 & The business location is very strategic & 0,345 \\
\hline 5 & The selling price of business product is relatively the same as the competitor & 0,285 \\
\hline \multirow[t]{2}{*}{6} & $\begin{array}{l}\text { There are various types of MSME which are available with their respective } \\
\text { advantages }\end{array}$ & 0,560 \\
\hline & Total Strength Score & 2,265 \\
\hline No & Strategic Factors of Internal Weakness & Score \\
\hline 1 & No promotional activities & 0,120 \\
\hline 2 & Small working capital & 0,1275 \\
\hline 3 & $\begin{array}{l}\text { Government policies that are less conducive, especially the implementation of } \\
\text { one-way street }\end{array}$ & 0,130 \\
\hline 4 & The low use of technology & 0,1125 \\
\hline 5 & Lack of external contributions & 0,105 \\
\hline & Total Weakness Score & 0,595 \\
\hline & Total Score of Internal Strategic Factors & 2.86 \\
\hline
\end{tabular}

Source:Primary Data, Data processed 2018

(1) The results of this study showed that $60 \%$ of respondents stated that the existence of this one-way street policy became the main problem in running their business with the reason that the accessibility of the road had decreased. And t Technology, This research covers the development of technology in MSME sector, the development of technology on business benefits that can be done by utilizing applications that can be easily obtained using smartphone.

(1) As much as $38.5 \%$ of the total respondents who utilize this technology, (social media, and registered their business into an online application (go-food and grab-food)). (2) The development of technology carried out by the UMKM actors mostly states that it affects the income.Basedon the SWOT analysis, the strengths, weakness, opportunities and threats, strenghts, weaknesses, opportunity and threats of Micro and Small and Medium Enterprises (MSME) are as follows:

The strategic position of Micro, Small and Medium Enterprises (MSME) in MH Thamrin - Gajah Mada Street used business strength matrix analysis, Which analyzed the business attractiveness and competitiveness of MSME sector by utilizing the results of SWOT analysis, then compiling SWOT diagram. 
Tabel 9. Score External Factor Evaluation

\begin{tabular}{|c|c|c|}
\hline No & Strategic Factors of External Opportunity & Score \\
\hline 1 & The use of technology that can support the business & 0,500 \\
\hline 2 & Good social conditions between entrepreneurs & 0,075 \\
\hline 3 & Innovation in running the business & 0,325 \\
\hline 4 & Coaching for MSME owners & 0,285 \\
\hline 5 & Can open similar businesses elsewhere to increase income. & 0,210 \\
\hline 6 & Can do better promotional strategy to attract many consumers. & 0,540 \\
\hline \multicolumn{3}{|c|}{ Total Opportunity Score } \\
\hline No & Strategic Factors of External Threat & Score \\
\hline 1 & Government policies that are not optimal & 0,340 \\
\hline 2 & There is no help from the government in business development & 0,195 \\
\hline 3 & There is conflict between employers and the government & 0,150 \\
\hline 4 & Low level of accessibility & 0,210 \\
\hline 5 & $\begin{array}{l}\text { There is no formal promotion, so maybe there is no upcoming development of } \\
\text { new buyers }\end{array}$ & 0,240 \\
\hline \multicolumn{2}{|r|}{ Total Threat Score } & 1,135 \\
\hline & Total Score of External Strategic Factors & 3,07 \\
\hline
\end{tabular}

Source:Primary Data, Data processed 2018

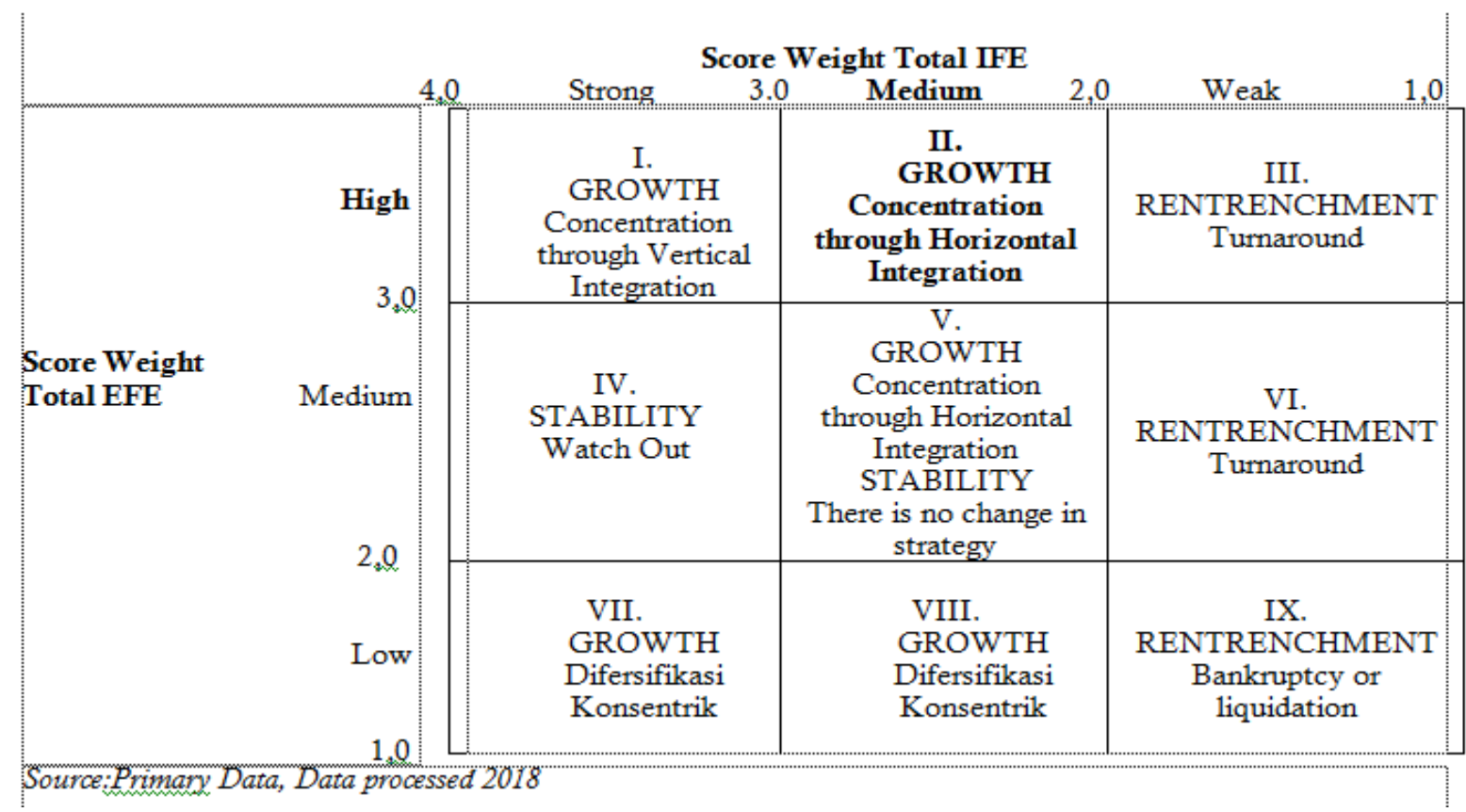

Figure 1. Strategic Position of Micro, Small and Medium Enterprises (MSME) in Goods and Services sector at MH Thamrin-Gajah Mada StreetTotal Weight Score of IFE 
The picture above shows that the strategic development of MSME business along $\mathrm{MH}$ Thamrin-Gajah Mada Street in Semarang City is in the second division.The second division is a division of growing and building stage with concentration through horizontal integration, (David, 2012). So,strategic development of MSME sector in MH Tahmrin-Gajah Mada Street, Semarang City is developing business in another place, coaching business by related agencies, business innovation, creating promotions with social media, training, maintaining selling prices of the product, and coordination between agencies related to the owner of business.

\section{CONCLUSION}

Based on the result of Paired-Samples T test, theincome variableaveragely experienced a significant decline in change. This is shown on the results $0.000<0.05$ which means that there is significant difference for goods and service businesses. The results for MSME in Goods sector indicate that the merchant income after the implementation of policy averagely decreased by $34 \%$. Whereas for services sector after the implementation of policy the income of service sector averagely decreased by $40 \%$. The results of SWOT analysis showed that the IFE (Internal Factor Evaluation) and EFE (External Factor Evaluation) scores were 2.86 and 3.07, respectively. This result explains that the direction of strategic development of MSME is in cell II (market penetration, market development, product development), which is in the growth and development stage, so that strategic developmetof MSMEin $\mathrm{MH}$ tahmrin-Gajah Mada Street Semarang City is developing business in another place, coaching business by related agencies, business innovation, creating promotions with social media, training, maintaining product selling prices, and coordination between agencies related to the business actor. Suggestions in this study for the Government, should review the one-way street policy which is implemented in $\mathrm{MH}$ Thamrin-Gajah Mada street in Semarang City due to considerations that arise frombad economic side of the community as the impact of the implementation ofpolicy. For business actors, they can do marketing in telemarketing by utilizing internet technology by using social media or other forms of application so that consumers can easily access information about the products that they have.

\section{REFERENCES}

Amiliyatus, S. N., \& Ashar, K. (2015). Analisis Perubahan Permintaan Dan Pendapatan Sektor UMKM Sebagai Dampak Perubahan Kebijakan Pemerintah Daerah. Fakultas Ekonomi dan Bisnis Universitas Brawijaya, 5 .

Aprilia, R. (2018). Dampak Revitalisasi Pasar Tradisional Terhadap Pendapatan Pedagang di Pasar Bulu Semarang. Economics Development Analysis Journal, 6(2), 215-220. https://doi.org/10.15294/edaj.v6i2.22219

Burhani, R. (2017, Febuari Kamis). Jalan searah di Semarang turunkan omzet pedagang. Retrieved Januari Senin, 2018, from https://www.antaranews.com/berita/614290/jal an-searah-di-semarang-turunkan-omzetpedagang

David, F. R. (2006). Manajemen Strategi: KonsepKonsep. Edisi Ke-sepuluh. Jakarta: Salemba Empat.

Direktorat Lalu Lintas, Polda Jateng, Jumlah Kendaraan Pribadi Kota Semarang Tahun 20122016.

Dwi, A. (2017, Febuari Selasa). Omzet Pelaku Bisnis Merosot. Retrieved Januari Senin, 2018, from http://radarsemarang.com/2017/o2/o1/omzetpelaku-bisnis-merosot/

Farasolina, R. (2018, Januari Rabu). Dampak Jalur Dua Arah Jalan Thamrin, Dishub Lakukan Pantauan. Retrieved January Senin, 2018, from Asatu.id: 
http://asatu.id/2018/o1/31/dampak-jalur-duaarah-jalan-thamrin-dishub-lakukan-pantauan/

Hamid, E. S., \& Susilo, Y. S. (2011). Strategi Pengembangan Usaha Mikro Kecil Dan Menengah Di Provinsi Daerah Istimewa Yogyakarta. Jurnal Ekonomi Pembangunan, Volume 12, Nomor 1, 45-55.

Hayati, N. N., Hasanudin, A., \& Setiawan, G. F. (2015). Evaluation Of One Way Traffic Flow Policy Changes In City Of Jember. The 18th FSTPT International Symposium, Unila, Bandar Lampung, .

Hudalloh, M., Sujai, A. I., \& Budi, W. (2014). Pengaruh Kebijakan Jalur Satu Arah Terhadap Penerimaan Penjualan Umkm Kota Malang Studi Kasus Umkm Sektor Tradisional Lingkar Brawijaya Meliputi Jalan Sumbersari, Jalan Gajayana, Jalan Mayjen Panjahitan. JEMA, Vol. 12 No. 2 Agustus 2014.

Pengolahan Data Statistik dengan SPSS 16.o. (2010). Jakarta: Salemba Infotek.

Peraturan Daerah Kota Semarang Nomor 2 Tahun 2002 Tentang Rencana Detail Tata Ruang Kota (RDTRK) Kotamadya Daerah Tingkat II Semarang Bagian Wilayah Kota I (BWK 1).

Permadi, A. (2015). STRATEGI PENGEMBANGAN INDUSTRI KECIL CARICA. JEJAK: Jurnal
Ekonomi dan Kebijakan, 8(1).doi:https://doi.org/10.15294/jejak.v8i1.3853

Putri, U. E., \& Muddakir, Y. B. (2013). Dampak Penataan Kawasan Simpanglima Kota Semarang Terhadap Pendapatan Pedagang Makanan. Diponegoro Journal Of Economics, Volume 2, Nomor 3 .

Rangkuti, F. (2015). ANALISIS SWOT : Teknik Membedah Kasus Bisnis, Cara Perhitungan Bobot, Rating, dan OCAI. Jakarta: Kompas Gramedia.

Triyaningsih, S. L. (2012). Strategi Pemasaran Usaha Kecil dan Menengah. Jurnal Ekonomi dan Perusahaan Fakultas Ekonomi Slamet Riyadi Surakrta , 2.

Wibisono, R. (2017, Februari Jumat). Jalan Searah Bikin Anjlok Omzet Pedagang. Retrieved January Senin, 2018, from Solo Pos.com: http://www.solopos.com/2017/o2/24/lalu-lintassemarang-jalan-searah-bikin-anjlok-omzetpedagang-79597.

Fafurida., Setiawan, AB., Irmawati, S. (2016). A Strategy to Increase the Competitiveness of Leading Industries in Central Java Province to Face ASEAN Economics Community 2015. IJEFI : International Journal of Economics and Financial Issues, 6(S6), 6o-66. 